\title{
Removal Torque of Zirconia Abutment Screws under Dry and Wet Conditions
}

\author{
Frederico NIGRO ${ }^{1}$ \\ Claudio L. SENDYK ${ }^{2}$ \\ Carlos Eduardo FRANCISCHONE Jr. ${ }^{3}$ \\ Carlos Eduardo FRANCISCHONE ${ }^{3}$ \\ ${ }^{1}$ Dental School, Sagrado Coração University, Bauru, SP, Brazil \\ ${ }^{2}$ Dental School, University of São Paulo, São Paulo, SP, Brazil \\ ${ }^{3}$ Oral Implantology Program, Dental School, Sagrado Coração University, Bauru, SP, Brazil
}

\begin{abstract}
The aim of this study was to verify whether screw abutment lubrication can generate higher preload values compared to non-lubricated screws, a titanium abutment was screwed onto an implant analog and scanned with the Procera System to generate 20 zirconia abutments. MKIII Brånemark implants were clamped to a precision torque device, and the abutments were distributed in dry and wet groups with 10 specimens each. In the wet groups, the inner threads of the implants were filled with artificial saliva. All abutments were fastened with a Torqtite screw under $32 \mathrm{Ncm}$. Ten detorque measurements were performed per group pushing the reverse button of the Torque controller soon after screw tightening with values registered. The mean detorque values were calculated and compared by a Student's $t$ test $(\alpha=0.05)$. The wet condition presented significantly higher mean detorque than the dry condition $(31.5 \pm 1.2$ versus $27.5 \pm 1.5$ $\mathrm{Ncm}$, respectively; $\mathrm{p}=0.0000024)$. In conclusion, there was always a loss in the initial torque values when the removal torque was measured under both conditions. The wet condition presented higher mean torque than the dry condition. Better preload values were established in the wet group, suggesting that the abutment screw must be lubricated in saliva to avoid further loosening.
\end{abstract}

Key Words: Dental implants, abutment screw, zirconium oxide, torque tightening, preload.

\section{INTRODUCTION}

Osseointegrated implants is a good represent now an acceptable treatment modality for complete or partially edentulous patients. Despite the recognized success, mechanical failures associated with singleimplant restorations represent a challenge to clinicians. Among the types of mechanical failures, abutment screw loosening is still the most frequently reported in the literature (1-5). Clinically, this issue is too critical in cemented restorations: first, crowns cannot be removed intact in most situations; second, crown loosening can lead to oblique forces at implant-abutment junction and screw fracturing.

Over the years, there have been works evaluating the behavior of abutment screws after loading, as well as attempts to improve their mechanical properties by modification/deposition of functional layers. However, few studies have considered the role of lubrication on detorque values. (6-10). Tzenakis et al. (10) verified that after 10 repetitions using slotted gold prosthetic screws under human salivary contamination, the preload values increased up to $16.3 \%$ of the original values.

Byrne et al. (11) found that all screw types displayed some decay in preload with repeated tightening, irrespective of abutment type and insertion toque, but the gold-coated screw still showed higher preloads for all insertion torques (10, 20 and $35 \mathrm{Ncm}$ ). Similarly, Stüker et al. (12) found that generated preloads on gold screws are three times greater than on titanium screws. Finally, a finite element model found that the probability of obtaining a preload within $60 \%$ to $75 \%$ of yield strength is $0.02 \%$ for dry and $54.5 \%$ for lubricated environments (13).

The aim of this study was to evaluate the removal torque of zirconia abutment screws under dry and wet conditions. The tested hypothesis is that there are no differences on detorque values in both situations.

Correspondence: Prof. Frederico Nigro, Rua Botucatu, 572 cj 11, Vila Clementino, 04023-061 São Paulo, SP, Brasil. Tel: +55-11-5574-8550. e-mail:nigro6@terra.com.br 


\section{MATERIAL AND METHODS}

In this protocol, the detorque values were tested under dry and wet conditions. An implant replica was positioned vertically with the aid of a dental surveyor and embedded in a PVC ring containing clear autopolymerizing acrylic resin. After, a titanium abutment was screwed onto and the implant replica. The Procera System (Model 050; Nobel Biocare, Yorba Linda CA, USA) was used to scan the abutment and get all relevant information on size and contours. Data was sent to the Procera workstation and twenty zirconia abutments (W-U-Hex R.P.ZRW/S, Nobel Biocare, Göteborg, Sweden) were made of similar dimensions (Fig. 1).

After, 20 MKIII turned implants $(13 \mathrm{~mm}$ in length, $3.75 \mathrm{~mm}$ in diameter, lot no. 28887, Nobel Biocare, Sweden) were attached to the clamp of a precision torque device (Tohnichi model BTG60cN-S (503500R); Tohnichi Mfg. Co. Ltd., Tokyo, Japan). In this way, the zirconia abutments were divided into dry and wet groups with 10 specimens each. In the wet condition, the inner threads of the implants were filled with artificial saliva (Oral Balance, 42 g, USA).

In both groups, the zirconia abutments were fastened first with a manual torque driver (Unigrip, lot no.29153; Nobel Biocare, Sweden) using a Torqtite screw (lot no. 29283; Nobel Biocare, Sweden) and after with a Torque Controller (DEA 059; Nobel Biocare, Sweden) under $32 \mathrm{Ncm}$. (Fig. 2).

Soon after, the reverse button of the Torque

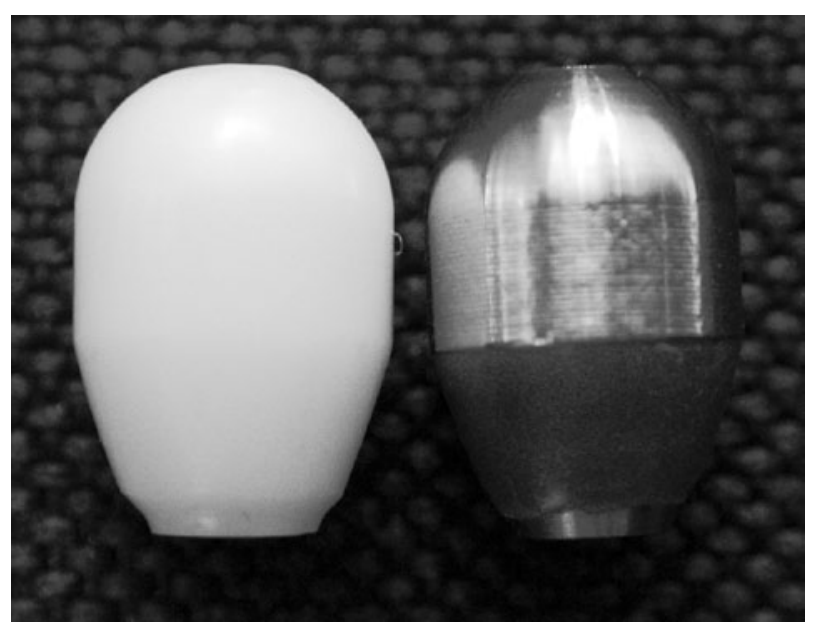

Figure 1. Titanium (right) and the zirconia (left) Procera abutments.
Controller was pushed and the detorque value registered with the aid of the torque precision device. This procedure was repeated ten times for each specimen, and the mean detorque values of both groups considered for statistical analysis.

Normality and Equal Variance tests revealed parametric data distribution. Therefore, the Student's $t$ test $(\alpha=0.05)$ was used to verify possible significant differences between mean detorque values of dry and wet groups.

\section{RESULTS}

The mean detorque values for the dry and wet conditions were $27.5 \pm 1.5 \mathrm{Ncm}$ and $31.5 \pm 1.2 \mathrm{Ncm}$, respectively. The Student's $t$ test revealed a statistically significant difference between these conditions, with better result for the wet condition $(\mathrm{p}=0.0000024)$.

\section{DISCUSSION}

The longevity of implant-supported prosthesis can be influenced by several biomechanical aspects: passive fit, machining precision, implant/abutment stability, etc. $(5,7,14)$. In single-tooth implant restorations, instability of implant/abutment connection has been clinically demonstrated.

Jemt et al. (3) observed that $43 \%$ of abutment screws in single-tooth restorations became unstable at least once in the first year, and the same author in 1991 showed through a clinical study that $26 \%$ of these screws need be retightened during the first year of function.

According to McGlumphy (14), when two parts are fastened by a screw, the screw will back out only when the external applied forces are greater than

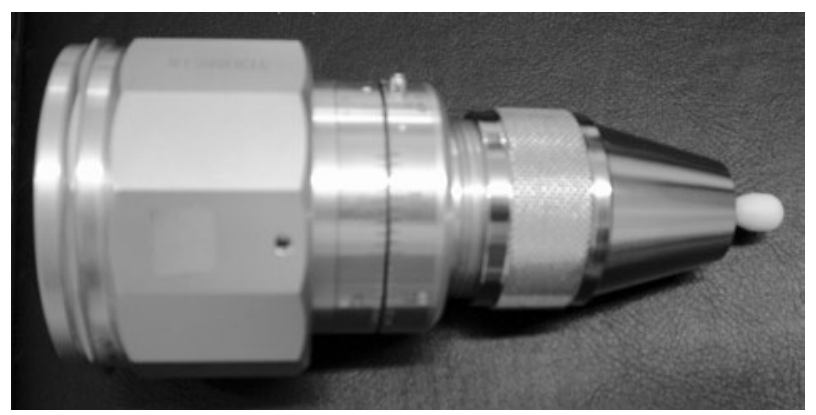

Figure 2. Implant-abutment clamped in the Tohnichi torque meter with the Torqtite screw. The abutment screw is tightened with the head of the Torque Controller. 
the internal forces (clamping force). In this way, the main consideration is the force developed in response to torque application, known as preload. Haack et al. (15) stated that the preload keeps the screw threads in close contact with the implant threads, generating a clamping force between the screw head and the seating platform. According to those authors, preload values are determined by: torque application, screw alloy type, screw head design, abutment alloy, implant surface, and lubrication.

Previous studies (16-18) have found that screws with a modified alloy have a lower coefficient of friction, which can result in higher preload values between the threads.

In the present work, it was observed that the Torqtite screws developed a higher preload. In the same way, the fit of screw head at the abutment screw participates on the union stability and improves the preload, being a direct relationship with the material hardness. Thus, that the zirconia abutment has a high mechanical resistance and hardness, which contributes to an improvement on the initial preload values.

Weiss et al. (19) registered the loss of torque values on repeated opening and closing cycles of several abutment screw systems. Immediate losses of 3 to $20 \%$ were registered, and in the Brånemark system there was loss of $20 \%$ in the first cycle, $31 \%$ after 5 cycles, and $36 \%$ after 15 cycles. However, those authors made evaluations only in dry conditions. Schulte and Coffey (20) observed that removal torque values were of $80 \%$ from the original torque values.

In this study, loss of the initial torque values was observed, as previously reported (19). However, $15 \%$ was lost in the dry group, similar to the work by Schulte and Coffey (20), and only $1 \%$ in the wet group. So, the working hypothesis must be rejected, since the results indicate a better performance in the group lubricated by artificial saliva. Thus, system lubrication directly interferes in the initial torque value, further generating higher preloads. This can prevent screw loosening, which confirms the findings of a previous study, which showed an increase on the initial preload values after consecutive removal torque tests in the presence of human saliva. Also, the present values were different from those of Al Rafee et al. (6), who found no significant differences between lubricated and nonlubricated screw threads. However, there is no detailed description on how abutment threads were lubricated. In our work, the internal threads of the implants were filled with artificial saliva.

It is still necessary to explain how lubrication could have generated higher preload values in the present work. First, one possible explanation is that during screw tightening, sliding friction is generated between the abutment screw threads and the internal threads of implants. This friction is not uniformly distributed. An intervening humid media certainly eliminates most of internal produced shear forces on threads, considering that all the internal implant portions were filled with artificial saliva. Second, as the abutment threads reach their final position inside the implant, some areas on the sides and valleys of the threads could not be wetted by saliva. So, non-uniform friction would develop under detorque forces resulting in final values higher than the first observed ones. Third, if the second hypothesis is not proven, it is possible that wetting can contribute to more apical thread levels; in this sense, there is no way for embedment relaxation (settling), and loss of applied torque is minimal.

In conclusion, there is always loss in the initial torque when the removal torque is measured in both conditions. The wet group (lubricated with artificial saliva) demonstrated a higher detorque value than the dry group. These results suggested that a better initial preload is obtained under wet conditions, which reflects the main role of abutment screw lubrication during installing and torque of these components.

\section{RESUMO}

A fim de verificar se a lubrificação do parafuso do pilar pode gerar valores maiores de pré-carga do que nos parafusos não lubrificados, um pilar de titânio foi parafusado no análogo do implante e escaneado pelo Sistema Procera para gerar 20 pilares de zircônia. Depois, os implantes MKIII Brånemark foram presos num dispositivo de torque. Os pilares foram distribuídos em grupos seco e úmido com 10 amostras cada. No grupo úmido, as roscas internas dos implantes foram preenchidas com saliva artificial. Então, todos os pilares foram apertados com parafuso Torqtite a $32 \mathrm{Ncm}$. Dez medidas de destorque foram realizadas por grupo apertando-se o botão reverso do Torque Controller logo depois do parafusamento, e os valores foram registrados. As medias de destorque foram calculadas e comparadas pelo teste $\mathrm{t}$ de Student $(\alpha=0,05)$. Os valores médios obtidos nas condições seca e úmida foram 27,5 $\pm 1,5 \mathrm{Ncm}$ e 31,7 $\pm 1,2 \mathrm{Ncm}$, respectivamente. Diferenças estatisticamente significantes foram observadas $(p=0,0000024)$. Observou-se sempre existir uma perda do torque inicial quando o torque de remoção é mensurado em ambas as condições. A condição úmida demonstrou um valor médio maior de torque do que a condição seca. Valores melhores de pré-carga podem ser estabelecidos no grupo úmido, sugerindo que o parafuso do pilar deve ser lubrificado em saliva para evitar seu afrouxamento. 


\section{REFERENCES}

1. Balshi TJ, Hernandez RE, Pryszlak MC, Rangert B. A comparative study of one implant versus two replacing a single molar. Int J Oral Maxillofac Implants 1996;11:372-378.

2. Jemt T, Laney WR, Harris D, Henry PJ, Krogh PH Jr, Polizzi $\mathrm{G}$ et al.. Osseointegrated implants for single tooth replacement: a 1-year report from a multicenter prospective study Int J Oral Maxillofac Implants 1991;6:29-36.

3. Jemt T, Lekholm U, Gröndahl K. 3-year follow-up study of early single implant restorations ad modum Branemark. Int $\mathrm{J}$ Periodontics Restorative Dent 1990;10:340-349.

4. Laney WR, Jemt T, Harris D, Henry PJ, Krogh PH, Polizzi G et al. Osseointegrated implants for single-tooth replacement: progress report from a multicenter prospective study after 3 years. Int J Oral Maxillofac Implants 1994;9:49-54.

5. Taylor TD. Prosthodontic problems and limitations associated with osseointegration. J Prosthet Dent 1998;79:74-78.

6. Al Rafee MA, Nagy WW, Fournelle RA, Dhuru VB, Tzenakis GK, Pechous CE. The effect of repeated torque on the ultimate tensile strength of slotted gold prosthetic screws. J Prosthet Dent 2002;88:176-182.

7. Burguete RL, Johns RB, King T, Patterson EA. Tightening characteristics for screwed joints in osseointegrated dental implants. J Prosthet Dent 1994;71:592-599.

8. Merz BR, Hunenbart S, Belser UC. Mechanics of the implantabutment connection: an 8-degree taper compared to a butt joint connection. Int J Oral Maxillofac Implants 2000;15:519-526.

9. Strub JR, Gerds T. Fracture strength and failure mode of five different single-tooth implant-abutment combinations. Int $\mathrm{J}$ Prosthodont 2003;16:167-171.
10. Tzenakis GK, Nagy WW, Fournelle RA, Dhuru VB. The effect of repeated torque and salivary contamination on the preload of slotted gold implant prosthetic screws. J Prosthet Dent 2002;88:183-191.

11. Byrne D, Jacobs S, O'Connell B, Houston F, Claffey N. Preloads generated with repeated tightening in three types of screws used in dental implant assemblies. J Prosthodont 2006;15:164-171.

12. Stüker RA, Teixeira ER, Beck JC, da Costa NP. Preload and torque removal evaluation of three different abutment screws for single standing implant restorations. J Appl Oral Sci 2008;16:55-58.

13. Guda T, Ross TA, Lang LA, Millwater HR. Probabilistic analysis of preload in the abutment screw of a dental implant complex. J Prosthet Dent 2008;100:183-193.

14. McGlumphy EA, Mendel DA, Holloway JA. Implant screw mechanics. Dent Clin North Am 1998;42:71-89.

15. Haack JE, Sakaguchi RL, Sun T, Coffey JP. Elongation and preload stress in dental implant abutment screws. Int J Oral Maxillofac Implants 1995;10:529-536.

16. Martin WC, Woody RD, Miller BH, Miller AW. Implant abutment screw rotations and preloads for four different screw materials and surfaces. J Prosthet Dent 2001;86:24-32.

17. Drago CJ. A clinical study of the efficacy of gold-tite square abutment screws in cement-retained implant restorations. Int $\mathrm{J}$ Oral Maxillofac Implants 2003;18:273-278.

18. Lang LA, Kang B, Wang RF, Lang BR. Finite element analysis to determine implant preload. J Prosthet Dent 2003;90:539-546.

19. Weiss EI, Kozak D, Gross MD. Effect of repeated closures on opening torque values in seven abutment-implant systems. J Prosthet Dent 2000;84:194-199.

20. Schulte JK, Coffey J. Comparison of screw retention of nine abutment systems: a pilot study. Implant Dent 1997;6:28-31. 